\title{
KOMPOSISI KIMIA DAN UJI AKTIVITAS ANTIBAKTERI MINYAK KEMANGI (Ocimum americanum L.) TERHADAP BAKTERI Escherichia coli, Shigella sonnei, DAN Salmonella enteritidis
}

\author{
Asep Kadarohman, Gebi Dwiyanti, Yuni Anggraeni, dan Lela Lailatul Khumaisah* \\ Prodi Kimia Jurusan Pendidikan Kimia FPMIPA UPI, Bandung \\ Jl. Dr. Setiabudhi No. 229 Bandung 40154 Indonesia \\ *E-mail: lailatul_khumaisah@yahoo.com
}

\begin{abstract}
The chemical composition and antibacterial activity of basil oil (Ocimum americanum L.) against Escherichia coli, Shigella sonnei and Salmonella enteritidis have been determined. Basil oils were isolated from leaves and stems of basil (Ocimum americanum L.) with percolation method and analyzed by FTIR and GC-MS spectrometry. The antibacterial activity of basil oils were obtained by Agar diffusion method with various concentration (v/v) 2, 4, 6, 8, and 10\% with ethanol p.a. as negative control, thiamfenicol, and tetracycline $500 \mathrm{mg}$ as positive control. The produces essential oils from leaves and stems of basil by percolation are 1.06 and $0.22 \%$, respectively. There are 22 components of basil oil were identified, with a major component are citral (35.58\%) and neral (29.56\%). Basil oil has not effectively against Escherichia coli and Shigella sonnei but effectively against Salmonella enteritidis at concentration 8 and $10 \%$, with inhibition zone diameter are 10.25 and $10.93 \mathrm{~mm}$ respectively.
\end{abstract}

Key words: antibacterial activity, Escherichia coli, Ocimum americanum L., Shigella sonnei, Salmonella enteritidis

\section{PENGANTAR}

Diare merupakan penyakit infeksi saluran pencernaan yang disebabkan oleh bakteri, virus, dan parasit. Beberapa jenis bakteri penyebab diare diantaranya, yaitu Escherichia Coli, Salmonella enteritidis, dan Shigella sonnei. Diare apabila dibiarkan terus-menerus dapat mengakibatkan kematian karena penderita mengalami dehidrasi. Menurut data United Nations Children's Fund (UNICEF) dan World Health Organization (WHO) pada tahun 2009, diare merupakan penyebab kematian nomor 2 pada balita di dunia, nomor 3 pada bayi, dan nomor 5 bagi segala umur. Menurut Deresse dan Awde (2009), diare dan gastroenteritis (diare disertai muntah) adalah penyebab utama dari kematian dan gejala kesehatan yang menurun pada sebagian besar negara berkembang.

Untuk menghambat atau membunuh bakteri-bakteri penyebab diare yang terdapat pada saluran pencernaan umumnya digunakan obat-obatan yang mengandung antibiotik sintetis. Antibiotik sintetis memiliki beberapa kelemahan, selain harganya mahal, bakteri baik juga dapat ikut terbunuh. Penggunaan antibiotik yang berlebihan dapat mengakibatkan bakteri menjadi resisten. Efek samping yang ditimbulkan juga beragam, diantaranya gangguan saluran cerna, alergi, demam, gangguan darah, kelainan hati dan gangguan fungsi ginjal (Falah, 2007).
Salah satu alternatif untuk mengurangi konsumsi terhadap antibiotik sintetis adalah dengan mengonsumsi antibiotik alami yang bersumber dari tumbuhan untuk menghambat atau membunuh bakteri. Antibiotik alami selain harganya murah diharapkan efek samping yang ditimbulkan lebih rendah dibandingkan antibiotik sintetis.

Sejak zaman dahulu, masyarakat Indonesia sudah mengenal dan memakai tumbuhan berkhasiat obat sebagai salah satu upaya penanggulangan masalah kesehatan yang dihadapi. Kemajuan teknologi dan ilmu pengetahuan ternyata tidak mampu begitu saja menghilangkan arti pengobatan tradisional. Apalagi keadaan perekonomian Indonesia saat ini yang mengakibatkan harga obat-obatan modern menjadi mahal. Oleh karena itu, salah satu pengobatan alternatif yang dilakukan adalah meningkatkan penggunaan tumbuhan berkhasiat obat di kalangan masyarakat.

Minyak atsiri akhir-akhir ini menarik perhatian dunia, hal ini disebabkan karena minyak atsiri dari beberapa tumbuhan bersifat aktif biologis, diantaranya sebagai antibakteri (Holley dan Patel, 2005; Burt, 2004; Gill et al., 2002; Melendez dan Capriles, 2006; Samy, 2005; dan Wannissoma et al., 2005). Selain itu, minyak atsiri juga dapat dipergunakan sebagai bahan pengawet pada makanan dan sebagai antibiotik alami (Yuharmen dan Nurbalatif, 2002). 
Minyak atsiri (dikenal juga sebagai minyak eteris (aetheric oil), essential oil, minyak terbang, serta minyak aromatik) adalah kelompok besar minyak nabati yang berwujud cairan kental pada suhu ruang namun mudah menguap tanpa mengalami dekomposisi sehingga memberikan aroma yang khas, berasa getir, dan umumnya larut dalam pelarut organik serta tidak larut dalam air. Minyak atsiri banyak digunakan dalam industri minyak wangi, kosmetik, obat-obatan, dan makanan (Sastrohamidjojo, 2004).

Salah satu tumbuhan yang dipergunakan oleh masyarakat Indonesia sebagai bahan obat-obatan adalah kemangi (Ocimum spp.). Menurut tim peneliti dari Center for New Corps and Plant Products, Purdue University, Amerika Serikat, daun kemangi terbukti ampuh untuk menyembuhkan sakit kepala, pilek, diare, sembelit, cacingan dan gangguan ginjal. Beberapa spesies dari Ocimum spp. dilaporkan dapat digunakan sebagai biopestisida (Hadipoentyanti, 2008) dan sebagai repellent terhadap nyamuk Aedes aegypti (Kardinan, 2007).

Menurut Sirait (2008), tanaman kemangi mempunyai kandungan kimia utama sitral dan geraniol. Patharakon et al. (2010) mengemukakan bahwa senyawa sitral dapat melawan bakteri patogen Salmonella typhimurium pada makanan, sedangkan Inoyue et. al. (2000) menyatakan sitral memiliki aktivitas antibakteri yang tinggi, konsentrasi senyawa sitral $<6,25 \mathrm{mg} / \mathrm{l}$ telah mampu melawan enam jenis bakteri yaitu H. influenzae ATCC 33391, S. Pyogenes ATC 12344a, S. pneumoniae IP-692, S. pneumoniae PRC53, S. aureus FDA 209P JC-1 dan E. coli NIHJ JC-2.

Selain itu, Maryati (2007) menyatakan bahwa minyak daun kemangi (Ocimum basilicum L.) memiliki aktivitas antibakteri terhadap Staphylococcus aureus dan Escherichia coli, dengan konsentrasi bunuh minimal 0,5 dan $0,25 \% \mathrm{v} / \mathrm{v}$. Thaweboon (2009) telah menguji aktivitas antimikroba minyak atsiri Ocimum americanum $L$. terhadap bakteri patogen yang terdapat dalam mulut. Hasilnya menunjukkan bahwa minyak atsiri ini memiliki aktivitas antimikroba terhadap Streptococcus mutans, Lactobacillus casei, dan Candida albicans. Ketiga bakteri memiliki nilai MIC 0,04\% $\mathrm{v} / \mathrm{v}$ dan masing-masing memiliki nilai MCC sebesar 0,08 ; 0,$3 ;$ dan $0,08 \% \mathrm{v} / \mathrm{v}$.

Oleh karena itu, untuk mengetahui sejauh mana efektivitas minyak kemangi (Ocimum americanum L.) dalam menghambat bakteri penyebab diare dilakukan penelitian mengenai "Komposisi Kimia, dan Uji Aktivitas Antibakteri Minyak Kemangi (Ocimum americanum L.) terhadap bakteri Escherichia coli, Shigella sonnei, dan Salmonella enteritidis".

\section{BAHAN DAN CARA KERJA}

\section{Bahan}

Pada penelitian ini digunakan kemangi kering yang diperoleh dari pasar Ciroyom, Bandung. Bakteri Escherichia coli yang digunakan berasal dari Laboratorium Mikrobiologi FPMIPA UPI, bakteri Shigella sonnei dan Salmonella enteritidis dari Laboratorium Kesehatan Departemen Kesehatan RI. Bahan-bahan yang digunakan diantaranya air, $\mathrm{Na}_{2} \mathrm{SO}_{4}$ anhidrat, medium nutrien broth, medium KNA, medium SSA, etanol p.a, tetrasiklin, dan tiamfenikol.

\section{Peralatan}

Peralatan yang digunakan adalah satu set perkolator, spektrometer FT-IR (Fourier Transform Infrared) Shimadzu 8400, spektrometer GC-MS (Gas Chromatography Mass Spectrometry) Shimadzu QP 5050A, waterbath shaker, inkubator, mikropipet, dan seperangkat alat gelas lainnya.

\section{Cara Kerja \\ Determinasi Tumbuhan}

Determinasi dilakukan di Laboratorium Herbarium Sekolah Ilmu dan Teknologi Hayati Institut Teknologi Bandung (ITB) Bandung dengan mengamati bagian daun, batang dan bunganya.

\section{Isolasi Minyak Atsiri}

Daun dan batang kemangi kering dipisahkan dan ditimbang, masing-masing dimasukkan ke dalam labu dasar bulat $3000 \mathrm{ml}$, ditambahkan air, kemudian diperkolasi dengan beberapa variasi waktu, yaitu selama 1, 2, dan 3 jam. Suhu dijaga sekitar $120-130^{\circ} \mathrm{C}$. Minyak atsiri daun dan batang kemangi hasil perkolasi ditampung dalam botol, dan ditambahkan $\mathrm{Na}_{2} \mathrm{SO}_{4}$ anhidrat. Kemudian minyak kemangi didekantasi ke dalam botol gelap, lalu botol disimpan ke dalam lemari yang tidak terkena cahaya.

\section{Analisis dan Identifikasi Senyawa}

Analisis dan identifikasi senyawa dilakukan dengan menggunakan spektrometri FT-IR dan GC-MS. Dari hasil FT-IR diperoleh spektrum berupa puncak bilangan gelombang $\left(\mathrm{cm}^{-1}\right)$, sedangkan dari GC-MS dapat diketahui komponen yang terdapat pada minyak kemangi (Ocimum basilicum L.) hasil perkolasi. Adapun kondisi yang digunakan pada saat analisis GC-MS adalah:
Metode
: Terprogram
Detektor
: DB 5 MS
Suhu kolom
: $60^{\circ} \mathrm{C}$
Suhu detektor
: $300^{\circ} \mathrm{C}$ 
Waktu analisis : 29 menit

Volume injeksi : $0,2 \mu \mathrm{l}$

\section{Uji Aktivitas Antibakteri}

Minyak kemangi hasil perkolasi dibuat dengan berbagai konsentrasi (v/v) 2, 4, 6, 8, dan 10\% dengan menggunakan pelarut etanol p.a, setelah itu dimasukkan ke dalam botol gelap. Kemudian dihomogenkan dengan menggunakan homogenizer, lalu dimasukkan kertas cakram pada setiap botol.

Uji aktivitas antibakteri minyak kemangi dengan metode difusi agar dilakukan pada bakteri yang telah diaktivasi. Aktivasi dilakukan secara bertahap untuk setiap bakteri. Mula-mula isolat bakteri hasil subkultur diambil sebanyak 1 ose dan dipindahkan ke dalam labu Erlenmeyer yang berisi $10 \mathrm{ml}$ medium cair untuk kemudian diinkubasi dalam waterbath shaker selama 24 jam pada $120 \mathrm{rpm}$ dengan suhu inkubasi $37^{\circ} \mathrm{C}$.

Untuk bakteri Escherichia coli, cawan petri yang telah disterilisasi dan ditandai untuk 3 jenis konsentrasi, diisi dengan $1 \mathrm{ml}$ inokulum kemudian masukan $9 \mathrm{ml}$ medium KNA lalu dihomogenkan hingga merata dengan cara diputar di atas meja dan dibiarkan sampai memadat. Selanjutnya disimpan setiap cakram kertas yang telah direndam dalam larutan minyak atsiri dengan konsentrasi $0 \%$ (kontrol negatif), 2, 4, 6, 8, dan $10 \%$ pada cawan petri sesuai dengan tanda konsentrasi. Sebagai kontrol positif digunakan tetrasiklin $500 \mathrm{mg}$ dan tiamfenikol $500 \mathrm{mg}$ yang masing-masing dilarutkan dalam $10 \mathrm{ml}$ aquades. Selanjutnya diinkubasi selama 24 jam pada suhu $37^{\circ} \mathrm{C}$. Zona bening di sekitar cakram kertas diamati dan diukur dengan menggunakan jangka sorong.

Pada uji aktivitas bakteri Shigella sonnei dan Salmonella enteritidis, langkah yang dilakukan adalah memasukkan 1 $\mathrm{ml}$ inokulum dan $9 \mathrm{ml}$ medium SSA ke dalam cawan petri yang telah disterilisasi dan ditandai untuk 3 jenis konsentrasi, kemudian dihomogenkan sampai merata dengan cara diputar di atas meja dan dibiarkan hingga memadat. Selanjutnya setiap cakram kertas yang telah direndam dalam larutan minyak atsiri dengan konsentrasi $0 \%$ (kontrol negatif), 2, 4, 6, 8, dan 10\% disimpan pada cawan petri sesuai dengan tanda konsentrasi. Sebagai kontrol positif digunakan tetrasiklin $500 \mathrm{mg}$ dan tiamfenikol $500 \mathrm{mg}$ yang masing-masing dilarutkan dalam $10 \mathrm{ml}$ aquades. Selanjutnya diinkubasi selama 24 jam pada suhu $37^{\circ} \mathrm{C}$. Zona bening di sekitar cakram kertas diamati dan diukur dengan menggunakan jangka sorong.

Pengujian uji aktivitas antibakteri minyak kemangi terhadap ketiga bakteri tersebut dilakukan sebanyak 5 kali replikasi (Gomez dan Gomez, 2005).

\section{HASIL DAN PEMBAHASAN}

\section{Determinasi Kemangi}

Hasil determinasi menujukkan bahwa tumbuhan adalah:

Nama suku/famili : Lamiaceae

Nama jenis/spesies : Ocimum americanum L.

Sinonim

: Ocimum affricanum Lour., Ocimum canum Sims, Ocimum brachiatum Blume.

Nama umum

: Hoary basil, American basil(Inggris), Kemangi, Selasih putih (Indonesia), Surawung (Sunda).

\section{Isolasi Minyak Atsiri}

Isolasi minyak atsiri dari daun dan batang kemangi (Ocimum basilicum L.) dilakukan dengan berbagai variasi waktu, yaitu 1, 2, dan 3 jam. Randemen hasil isolasi dapat dilihat pada Tabel 1 .

Tabel 1. Randemen minyak kemangi

\begin{tabular}{ccccc}
\hline $\begin{array}{c}\text { Bagian } \\
\text { Kemangi }\end{array}$ & Massa & $\begin{array}{c}\text { Waktu } \\
\text { Perkolasi }\end{array}$ & $\begin{array}{c}\text { Ran- } \\
\text { demen }\end{array}$ & $\%$ \\
\hline Daun & $150 \mathrm{~g}$ & 1 jam & $1,2 \mathrm{ml}$ & 0,80 \\
& & 2 jam & $1,5 \mathrm{ml}$ & 1,00 \\
& & 3 jam & $1,6 \mathrm{ml}$ & 1,06 \\
Batang & $225 \mathrm{~g}$ & 1 jam & $0,3 \mathrm{ml}$ & 0,08 \\
& & 2 jam & $0,4 \mathrm{ml}$ & 0,17 \\
& & 3 jam & $0,5 \mathrm{ml}$ & 0,22 \\
\hline
\end{tabular}

Bagian daun Ocimum americanum L. mengandung minyak atsiri lebih banyak dari pada bagian batang. Semakin lama waktu perkolasi, maka semakin banyak minyak atsiri yang dihasilkan (Tabel 1).

\section{Analisis dan Identifikasi Senyawa}

Minyak atsiri hasil perkolasi yang telah dipisahkan dari komponen air dengan menambahkan $\mathrm{Na}_{2} \mathrm{SO}_{4}$ anhidrat selanjutnya dianalisis dengan menggunakan spektrometri FT-IR (Fourier Transform Infrared) dan GC-MS (Gas Chromatography Mass Spectrometry).

Pada spektra FTIR minyak kemangi (Gambar 1) menunjukan frekuensi rentangan $\mathrm{O}-\mathrm{H}$ sebagai puncak lebar kuat pada $3469,7 \mathrm{~cm}^{-1}$. Selain itu terdapat spektrum regangan karbonil $(\mathrm{C}=\mathrm{O})$ pada daerah $1674,1 \mathrm{~cm}^{-1}$. Terdapat serapan khas untuk C-H aldehida, yaitu pada bilangan gelombang 2761,9 dan 2856,4 $\mathrm{cm}^{-1}$. Bending C-H ditunjukkan pada bilangan gelombang 1444,6-1377,1 $\mathrm{cm}^{-1}$. Puncak serapan C-O muncul pada bilangan gelombang 1193 $\mathrm{cm}^{-1}$ (Silverstein, 1991). 


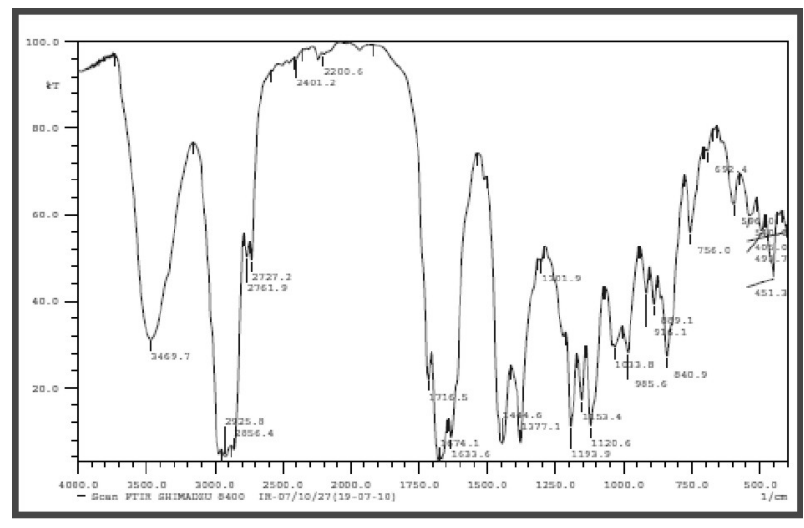

Gambar 1. Spektra FT-IR minyak kemangi

Hasil analisis GC-MS (Gambar 2) menunjukkan bahwa minyak kemangi memiliki 22 komponen penyusun.

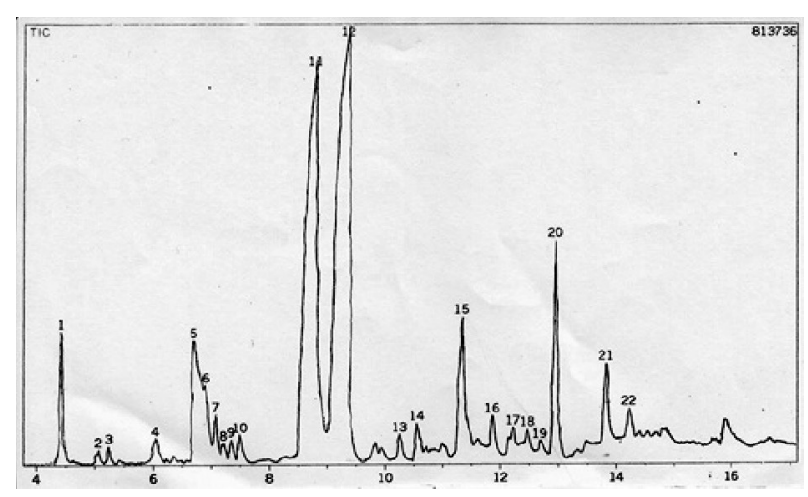

Gambar 2. Kromatogram GC-MS minyak kemangi

Dari ke-22 puncak yang terbentuk, hanya 7 puncak senyawa yang pola fragmentasinya memiliki nilai Similiarity Index $(\mathrm{SI}) \geq 90 \%$ dengan pustaka MS, dengan waktu retensi masing-masing 4,425; 6,692; 8,792; 9,367; 11,333; 12,950; dan 13,825 menit (Tabel 2).

Tabel 2. Komponen penyusun minyak kemangi

\begin{tabular}{|c|c|c|c|}
\hline $\begin{array}{l}\text { Waktu } \\
\text { Retensi } \\
\text { (menit) }\end{array}$ & Kelimpahan (\%) & Nilai SI & Senyawa \\
\hline 4,425 & 2,27 & 97 & $\begin{array}{l}\text { 6-metil-5-hepten- } \\
\text { 2-on }\end{array}$ \\
\hline 6,692 & 6,78 & 97 & Linalool \\
\hline 8,792 & 29,56 & 96 & Neral \\
\hline 9,367 & 35,58 & 96 & Sitral \\
\hline 11,333 & 5,05 & 90 & Isokariofilen \\
\hline 12,950 & 6,03 & 93 & $\alpha$ - humulen \\
\hline 13,825 & 2,18 & 94 & Kariofilen oksida \\
\hline
\end{tabular}

Berdasarkan kromatogram GC-MS, diketahui bahwa komponen utama muncul pada puncak $11(29,56 \%)$ dan 12 $(35,58 \%)$ dengan waktu retensi masing-masing 8,792 dan 9,367 menit. Puncak 11 memiliki pola fragmentasi seperti pada Gambar 3.

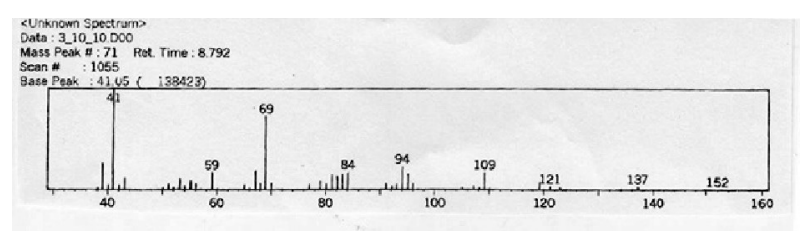

Gambar 3. Spektra massa puncak 11 dengan waktu retensi 8,792 menit.

Pada Gambar 3, terlihat bahwa senyawa tersebut mempunyai $\mathrm{M}^{+}$dengan $m / z$ sebesar 152 . Puncak ion dasar (base peak) muncul pada $m / z=69$ adalah fragmen yang dihasilkan dari pelepasan molekul $\mathrm{C}_{5} \mathrm{H}_{7} \mathrm{O}$ atau fragmen $\mathrm{M}-\mathrm{C}_{5} \mathrm{H}_{7} \mathrm{O}$. Jika dibandingkan dengan pustaka pada MS, senyawa ini merupakan senyawa neral dengan nilai SI (Similarity Index) sebesar 96\%. Kelimpahan senyawa tersebut pada minyak kemangi sebesar $29,56 \%$ dari total masukan $0,2 \mu 1$ atau sebesar 59,12 $\times 10^{-3} \mu 1$.

Adapun puncak 12 memiliki pola fragmentasi (Gambar 4).

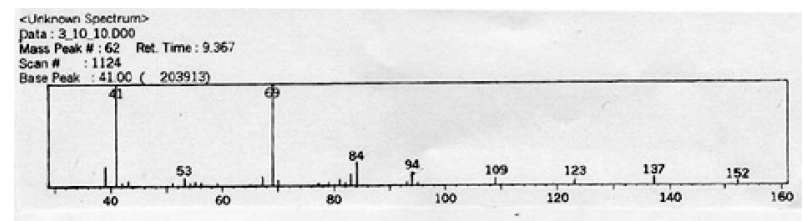

Gambar 4. Spektra massa puncak 12 dengan waktu retensi 9,367 menit.

Dari Gambar 4 dapat dilihat bahwa senyawa ini memiliki $\mathrm{M}^{+}$dengan $\mathrm{m} / \mathrm{z}$ sebesar 152. Puncak ion dasar (base peak) muncul pada $\mathrm{m} / \mathrm{z}=69$ yang merupakan fragmen yang dihasilkan dari pelepasan molekul $\mathrm{C}_{5} \mathrm{H}_{7} \mathrm{O}$ atau fragmen $\mathrm{M}$ $\mathrm{C}_{5} \mathrm{H}_{7} \mathrm{O}$. Berdasarkan pustaka MS, senyawa tersebut adalah sitral dengan nilai SI sebesar 96\%. Kelimpahan senyawa tersebut pada minyak kemangi adalah $35,58 \%$ dari total masukan $0,2 \mu \mathrm{l}$ atau sebesar $71,16 \times 10^{-3} \mu 1$.

\section{Uji Aktivitas Antibakteri}

Dari hasil pengujian aktivitas antibakteri minyak kemangi (Ocimum basilicum L.) terhadap bakteri Eschericia coli diperoleh data seperti pada Tabel 3. 
Tabel 3. Diameter zona hambat minyak kemangi terhadap bakteri Eschericia coli

\begin{tabular}{ccc}
\hline $\begin{array}{c}\text { Konsentrasi } \\
\text { (\%volum) }\end{array}$ & $\begin{array}{c}\text { Diameter Zona } \\
\text { Hambat }(\mathbf{m m})\end{array}$ & Efektifitas \\
\hline 2 & 5,68 & Tidak Efektif \\
4 & 6,14 & Tidak Efektif \\
6 & 6,50 & Tidak Efektif \\
8 & 6,80 & Tidak Efektif \\
10 & 7,80 & Tidak Efektif \\
\hline
\end{tabular}

Keterangan: Perhitungan diameter zona hambat termasuk dengan diameter kertas cakram (5 mm)

Konsentrasi minyak kemangi 2, 4, 6, 8, dan $10 \%$ terbentuk zona bening namun diameternya masih berada pada rentang tidak efektif yaitu $<8 \mathrm{~mm}$. Pada data tersebut seiring dengan bertambahnya konsentrasi, diameter zona hambat akan semakin meningkat (Tabel 3).

Adapun diameter zona hambat untuk bakteri Eschericia coli pada kontrol, baik negatif maupun positif disajikan pada Tabel 4.

Tabel 4. Diameter zona hambat bakteri Eschericia coli terhadap kontrol

\begin{tabular}{lcc}
\hline \multicolumn{1}{c}{ Kontrol } & $\begin{array}{c}\text { Diameter Zona } \\
\text { Hambat }(\mathbf{m m})\end{array}$ & Efektivitas \\
\hline $\begin{array}{l}\text { Kontrol (-) } \\
\text { Etanol p.a } \\
\text { Kontrol (+) }\end{array}$ & 5,00 & - \\
$\begin{array}{l}\text { Tetrasiklin } \\
50 \mathrm{mg} / \mathrm{ml}\end{array}$ & 21,60 & Sangat Efektif \\
$\begin{array}{l}\text { Tiamfenikol } \\
50 \mathrm{mg} / \mathrm{ml}\end{array}$ & Efektif \\
\hline $\begin{array}{l}\text { Keterangan: Perhitungan diameter zona hambat termasuk dengan } \\
\text { diameter kertas cakram (5 mm). }\end{array}$
\end{tabular}

Untuk mengetahui pengaruh konsentrasi minyak kemangi terhadap diameter zona hambat, maka dilakukan uji regresi. Pada uji tersebut apabila nilai regresi semakin mendekati linear maka diameter zona hambat dipengaruhi oleh konsentrasi (Gambar 5).

Dari Gambar 5, diperoleh nilai regresi sebesar 0,9428. Hal ini menyatakan bahwa diameter zona hambat pada pengujian aktivitas antibakteri minyak kemangi terhadap Eschericia coli dipengaruhi secara linear oleh konsentrasi. Diameter zona hambat akan bertambah menjadi efektif dengan memperbesar konsentrasi. Menurut Schegel (1994), kemampuan suatu bahan antimikroba dalam meniadakan kemampuan hidup mikroorganisme tergantung pada konsentrasi bahan antimikroba tesebut.

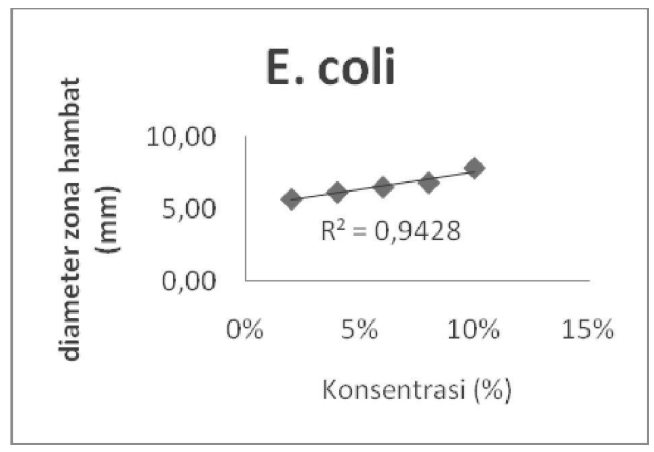

Gambar 5. Grafik hubungan diameter zona hambat bakteri Eschericia coli terhadap konsentrasi minyak kemangi.

Dokumentasi foto hasil uji aktivitas antibakteri minyak kemangi (Ocimum basilicum L.) terhadap bakteri Eschericia coli dapat dilihat pada Gambar 6, 7, dan 8.

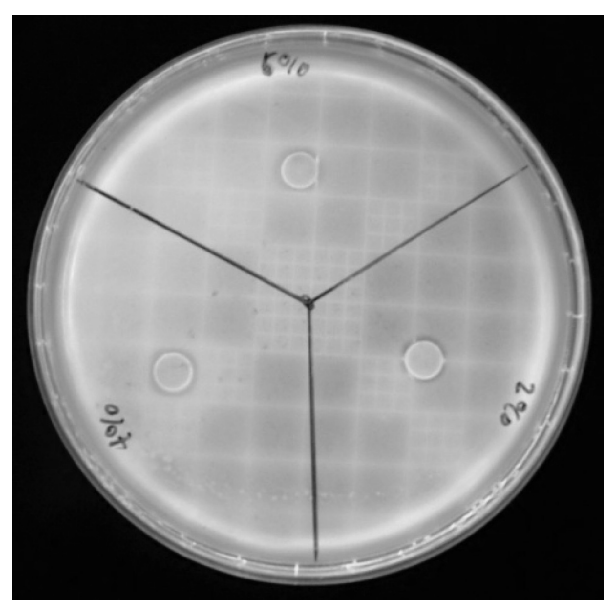

Gambar 6. Hasil uji aktivitas minyak kemangi terhadap Eschericia coli pada konsentrasi 2 , 4, dan $6 \%$

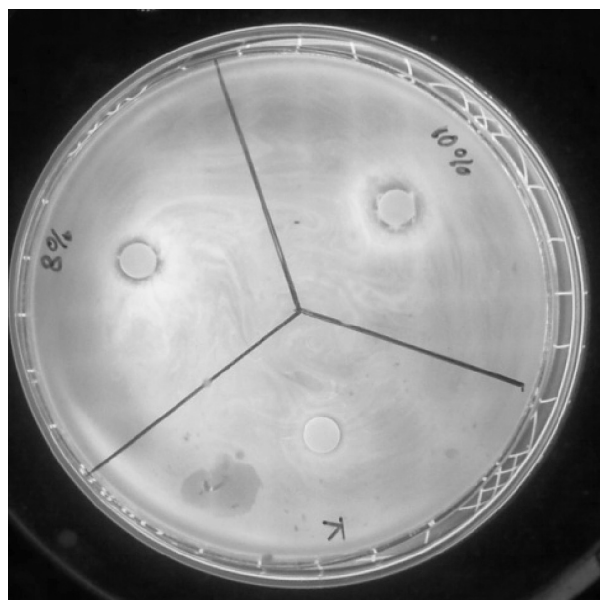

Gambar 7. Hasil uji aktivitas minyak kemangi terhadap Eschericia coli pada konsentrasi 8 dan $10 \%$ serta kontrol (-) 


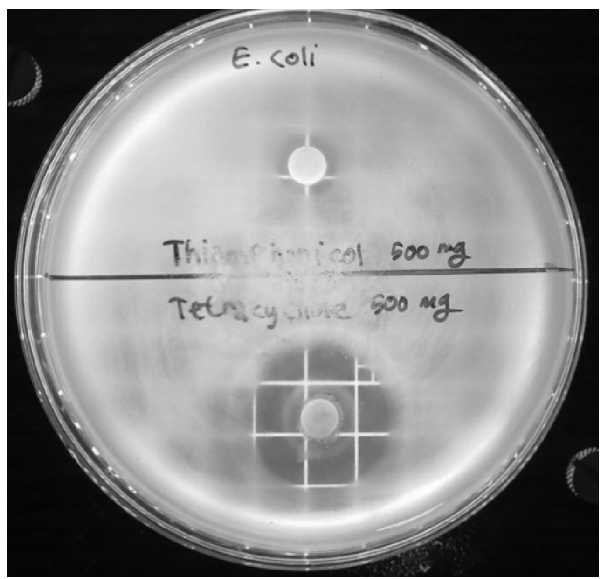

Gambar 8. Hasil uji aktivitas minyak kemangi terhadap Eschericia coli pada kontrol $(+)$

Untuk hasil pengujian aktivitas antibakteri terhadap Shigella sonnei disajikan pada Tabel 5 dan 6 .

Tabel 5. Diameter zona hambat minyak kemangi terhadap bakteri Shigella sonnei

\begin{tabular}{ccc}
\hline $\begin{array}{c}\text { Konsentrasi } \\
\text { (\%volum) }\end{array}$ & $\begin{array}{c}\text { Diameter Zona } \\
\text { Hambat }(\mathbf{m m})\end{array}$ & Efektivitas \\
\hline 2 & 5,35 & Tidak Efektif \\
4 & 5,85 & Tidak Efektif \\
6 & 6,10 & Tidak Efektif \\
8 & 6,19 & Tidak Efektif \\
10 & 6,64 & Tidak Efektif \\
\hline
\end{tabular}

Keterangan: Perhitungan diameter zona hambat termasuk dengan diameter kertas cakram (5 $\mathrm{mm})$.

Tabel 6. Diameter zona hambat bakteri Shigella sonnei terhadap kontrol

\begin{tabular}{lcc}
\hline \multicolumn{1}{c}{ Kontrol } & $\begin{array}{c}\text { Diameter Zona } \\
\text { Hambat }(\mathbf{m m})\end{array}$ & Efektivitas \\
\hline $\begin{array}{l}\text { Kontrol (-) } \\
\text { Etanol p.a }\end{array}$ & 5,00 & - \\
Kontrol (+) & & \\
$\begin{array}{l}\text { Tetracycline } 50 \\
\mathrm{mg} / \mathrm{mL}\end{array}$ & 43,67 & Sangat Efektif Sekali \\
Thiamphenicol & 38,05 & Sangat Efektif Sekali \\
$50 \mathrm{mg} / \mathrm{mL}$ & & \\
\hline
\end{tabular}

Keterangan: Perhitungan diameter zona hambat termasuk dengan diameter kertas cakram (5 $\mathrm{mm})$.
Berdasarkan Tabel 5, diketahui bahwa pada konsentrasi minyak kemangi $2,4,6,8$, dan $10 \%$, belum ada yang efektif menghambat bakteri karena diameter zona hambat masih $<8 \mathrm{~mm}$. Naiknya diameter zona hambat seiring dengan bertambahnya konsentrasi. Setelah dibuat grafik hubungan antara diameter zona hambat terhadap konsentrasi (Gambar 9), diperoleh nilai regresi 0,9502. Nilai regresi tersebut mendekati linear sehingga pada pengujian aktivitas antibakteri diameter zona hambat bakteri Shigella sonnei dapat menjadi lebih besar dan efektif dengan memperbesar konsentrasi minyak kemangi.

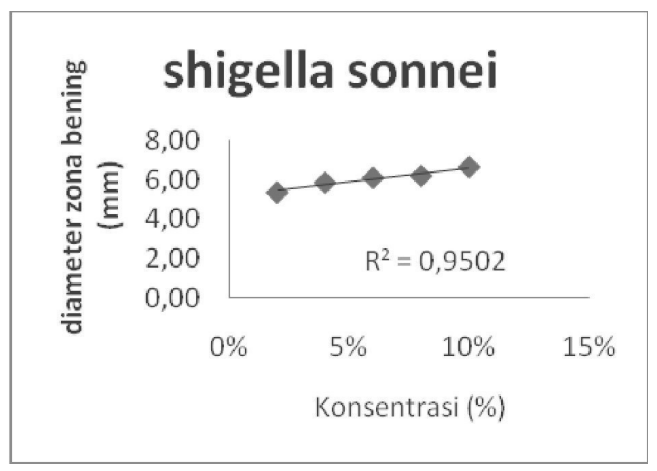

Gambar 9. Grafik hubungan diameter zona hambat bakteri Shigella sonnei terhadap konsentrasi minyak kemangi.

Dokumentasi foto hasil uji aktivitas antibakteri minyak kemangi (Ocimum basilicum L.) terhadap Shigella sonnei dapat dilihat pada Gambar 10, 11, dan 12.

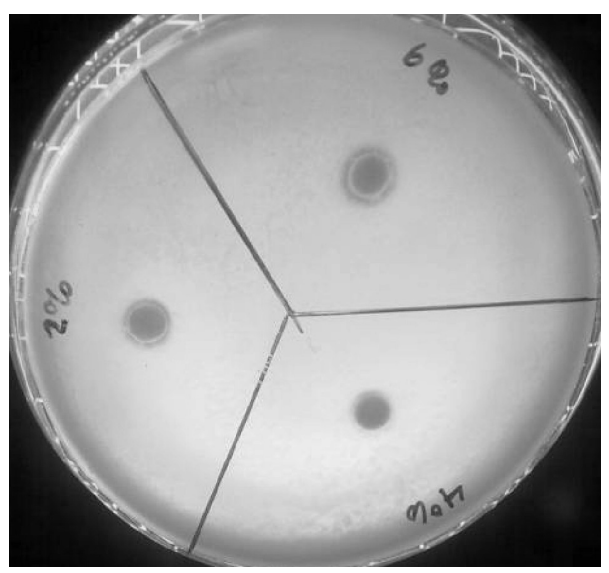

Gambar 10. Hasil uji aktivitas minyak kemangi terhadap Shigella sonnei pada konsentrasi 2, 4, dan $6 \%$ 


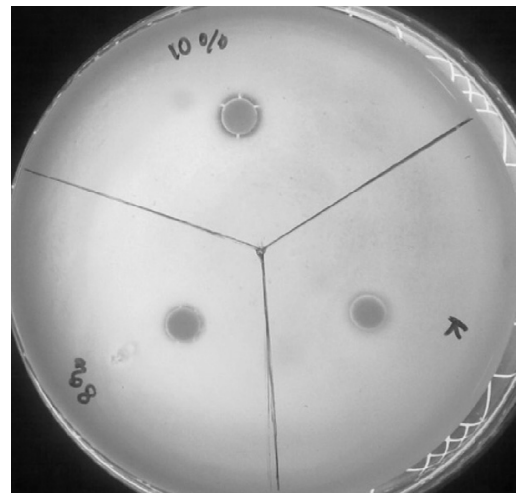

Gambar 11. Hasil uji aktivitas minyak kemangi terhadap Shigella sonnei pada konsentrasi 8 dan 10\% serta kontrol (-)

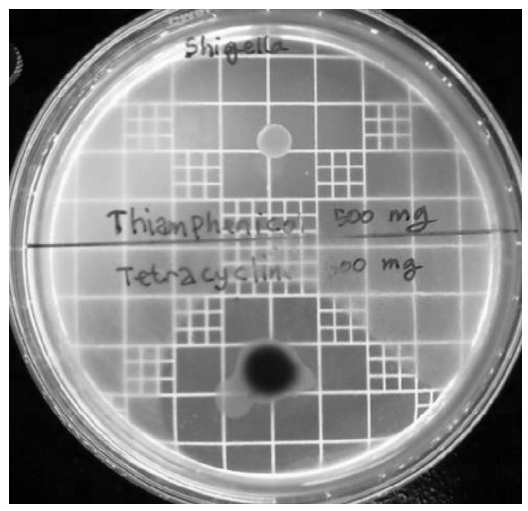

Gambar 12. Hasil uji aktivitas minyak kemangi terhadap Shigella sonnei pada kontrol $(+)$

Pada pengujian aktivitas antibakteri minyak kemangi terhadap Salmonella enteritidis diperoleh data seperti pada Tabel 7 dan 8.

Tabel 7. Diameter zona hambat minyak kemangi terhadap bakteri Salmonella enteritidis

\begin{tabular}{ccl}
\hline $\begin{array}{c}\text { Konsentrasi } \\
\text { (\% volum) }\end{array}$ & $\begin{array}{c}\text { Diameter Zona } \\
\text { Hambat }(\mathbf{m m})\end{array}$ & \multicolumn{1}{c}{ Efektivitas } \\
\hline 2 & 6,53 & Tidak Efektif \\
4 & 7,98 & Tidak Efektif \\
6 & 8,58 & Tidak Efektif \\
8 & 10,25 & Efektif \\
10 & 10,93 & Efektif \\
\hline
\end{tabular}

Keterangan: Perhitungan diameter zona hambat termasuk dengan diameter kertas cakram $(5 \mathrm{~mm})$.
Tabel 8. Diameter zona hambat bakteri Salmonella enteritidis terhadap kontrol

\begin{tabular}{lcc}
\hline \multicolumn{1}{c}{ Kontrol } & $\begin{array}{c}\text { Diameter Zona } \\
\text { Hambat }(\mathbf{m m})\end{array}$ & Efektivitas \\
\hline $\begin{array}{l}\text { Kontrol (-) } \\
\text { Etanol p.a }\end{array}$ & 5,00 & - \\
$\begin{array}{l}\text { Kontrol (+) } \\
\text { Tetracycline } 50\end{array}$ & 33,50 & \\
$\mathrm{mg} / \mathrm{mL}$ & 20,15 & $\begin{array}{l}\text { Sangat Efektif Sekali } \\
\text { Sangat Efektif Sekali }\end{array}$ \\
$\begin{array}{l}\text { Thiamphenicol } \\
50 \mathrm{mg} / \mathrm{mL}\end{array}$ & & \\
\hline $\begin{array}{l}\text { Keterangan: Perhitungan diameter zona hambat termasuk dengan } \\
\text { diameter kertas cakram (5 mm). }\end{array}$
\end{tabular}

Dari lima variasi konsentrasi minyak kemangi yang diuji terhadap bakteri Salmonella enteritidis, pada konsentrasi 8 dan $10 \%$ menujukan daya hambat yang efektif. Untuk mengetahui pengaruh konsentrasi terhadap zona hambat maka dilakukan uji regresi (Gambar 13). Pada uji tersebut menujukan nilai regresi sebesar 0,9805 . Nilai regresi mendekati linear sehingga dapat dikatakan bahwa besarnya konsentrasi pada minyak kemangi akan memengaruhi besarnya diameter zona hambat antibakteri secara linear.

\section{salmonella enteritidis}

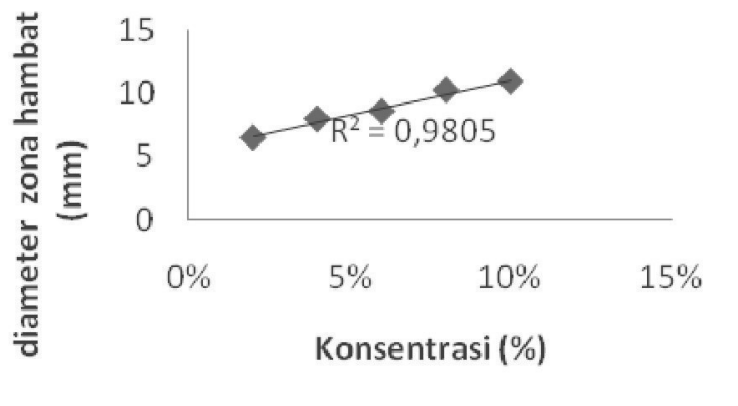

Gambar 13. Grafik hubungan diameter zona hambat bakteri Salmonella enteritidis terhadap konsentrasi minyak kemangi

Dokumentasi foto hasil uji aktivitas antibakteri minyak kemangi (Ocimum basilicum L.) terhadap bakteri Salmonella enteritidis dapat dilihat pada Gambar 14, 15, dan 16. 


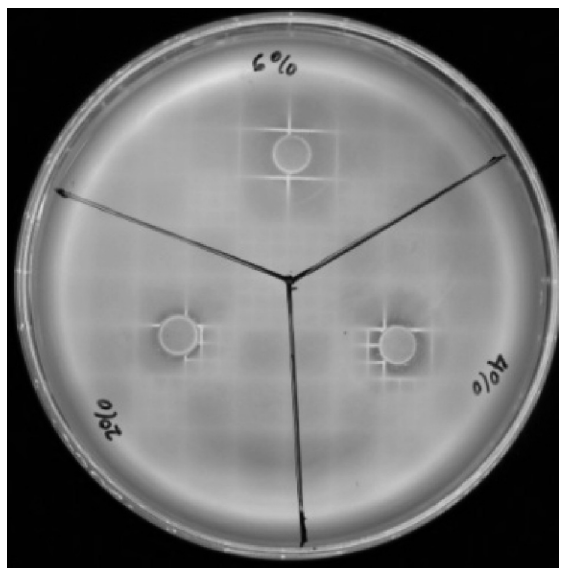

Gambar 14. Hasil uji aktivitas minyak kemangi terhadap Salmonella enteritidis pada konsentrasi 2, 4, dan 6\%

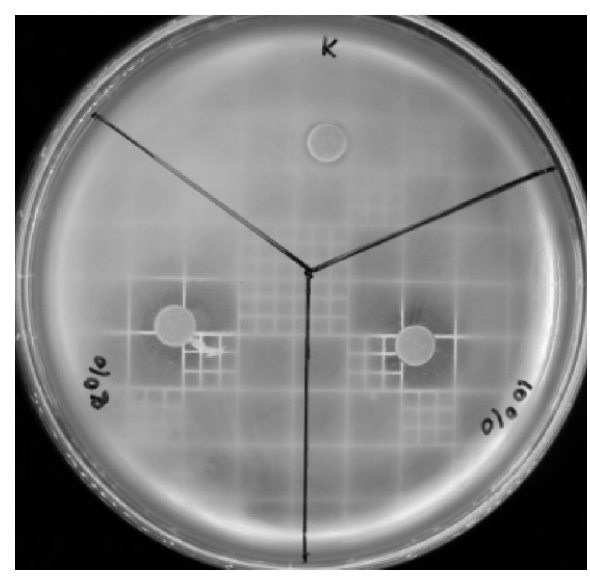

Gambar 15. Hasil uji aktivitas minyak kemangi terhadap Salmonella enteritidis pada konsentrasi 8 dan $10 \%$ serta kontrol (-)

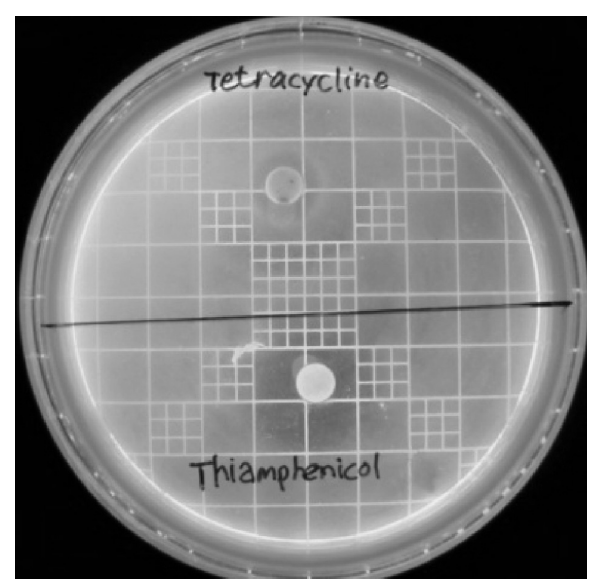

Gambar 16. Hasil uji aktivitas minyak kemangi terhadap Salmonella enteritidis pada kontrol $(+)$

Berdasarkan hasil pengukuran dan analisis, diameter zona hambat bakteri Salmonella enteritidis terbesar dihasilkan pada minyak kemangi dengan konsentrasi $10 \%$. Untuk mengetahui waktu yang dibutuhkan minyak kemangi dalam menghambat aktivitas bakteri secara efektif maka dilakukan uji aktivitas antibakteri yang diamati selang 2 jam selama 24 jam. Dari hasil pengamatan diperoleh grafik hubungan diameter zona hambat terhadap waktu (Gambar 17).

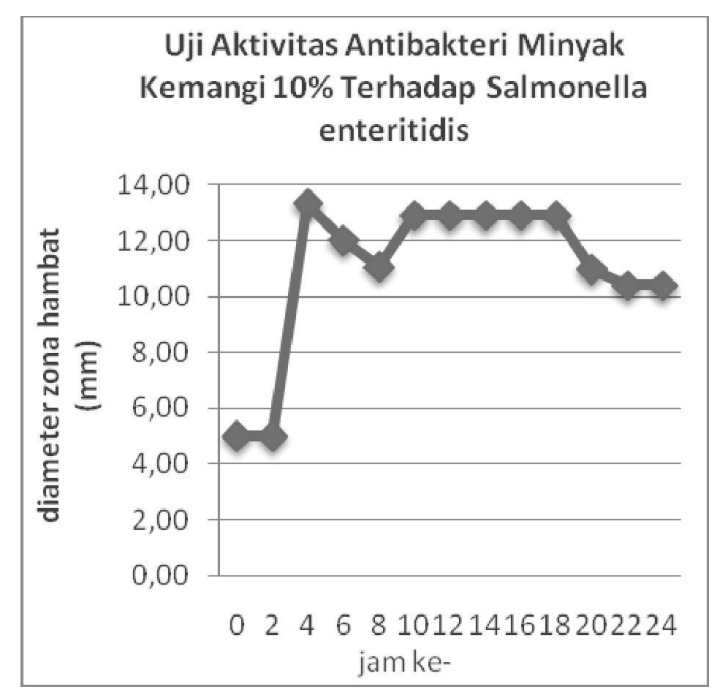

Gambar 17. Grafik hubungan diameter zona hambat minyak kemangi $10 \%$ pada Salmonella enteritidis terhadap waktu

Dari Gambar 17, dapat diketahui bahwa minyak kemangi dengan konsentrasi $10 \%$ bekerja efektif dalam menghambat aktivitas bakteri pada 4 jam pertama, dilihat dari terbentuknya diameter zona hambat sebesar 13,32 $\mathrm{mm}$ selama 4 jam. Grafik zona hambat yang dihasilkan turun pada jam ke- 8 dan naik kembali pada jam ke-10 lalu konstan kemudian turun kembali pada jam ke-18. Hal ini kemungkinan dipengaruhi oleh faktor-faktor yang mempengaruhi aktivitas zat antibakteri, diantaranya: $\mathrm{pH}$, suhu, stabilitas zat antibakteri, jumlah bakteri yang ada, lamanya inkubasi, dan aktivitas metabolisme bakteri.

Antibakteri adalah zat yang dapat mengganggu pertumbuhan atau bahkan mematikan bakteri dengan cara mengganggu metabolisme mikroba yang merugikan. Antibakteri hanya dapat digunakan jika mempunyai sifat toksik selektif, artinya dapat membunuh bakteri yang menyebabkan penyakit tetapi tidak beracun bagi penderitanya. Berdasarkan aktivitasnya zat antibakteri dibedakan menjadi dua jenis, yaitu bakteriostatik dan bakteriosida. Bakteriostatik adalah zat antibakteri yang memiliki aktivitas menghambat pertumbuhan bakteri (menghambat perbanyakan populasi bakteri), namun tidak 
mematikan. Sedangkan bakteriosida adalah zat antibakteri yang memiliki aktivitas membunuh bakteri.

Telah diteliti mengenai beberapa senyawa terpenoid yang aktif sebagai antibakteri. Senyawa yang bersifat antibakteri diantaranya eugenol, linalool, dan sitral (Knobloch et al., 1989). Senyawa sitral merupkan senyawa aldehid golongan monoterpen (tersusun dari 2 unit isopren), yang berasal dari hidrolisa geranil pirofosfat (GPP) menjadi linalool lalu mengalami oksidasi. Sitral merupakan salah satu senyawa yang terdapat pada minyak kemangi (Ocimum basilicum L.). Adapun struktur molekul senyawa sitral seperti pada Gambar 18.

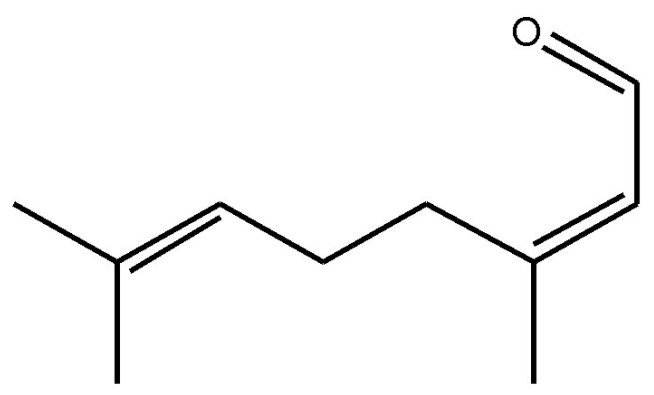

Gambar 18. Struktur molekul sitral

Mekanisme zat antibakteri dalam membunuh atau menghambat pertumbuhan bakteri bervariasi dan kompleks, umumnya dapat menyebabkan perubahan pada komponen makromolekul dari bakteri. Perubahan yang terjadi, yaitu rusaknya membran sel, membuat inaktif protein secara irreversible, dan menyebabkan kerusakan asam nukleat. Pengendalian mikroorganisme khususnya bakteri dapat dilakukan baik secara kimia seperti dengan pemberian antibiotik dan zat-zat kimia lainnya, ataupun pengendalian secara fisik seperti pemberian panas, pendinginan, radiasi, dan pengeringan (Kusnadi et al., 2003). Ada efek samping dalam penggunaan antibiotik seperti terbunuhnya bakteri baik yang terdapat dalam tubuh dikarenakan beberapa antibiotik tidak bekerja secara spesifik pada bakteri tertentu dan kemungkinan bakteri jahat akan kebal terhadap antibiotik karena perubahan mutasi.

Bakteri Escherichia coli, Shigella sonnei, dan Salmonella enteritidis yang tergolong ke dalam bakteri gram negatif ternyata kurang rentan terhadap zat antibakteri yang berasal dari minyak atsiri, dalam hal ini minyak kemangi. Menurut Inouye et al. (2000) bakteri gram negarif kurang rentan terhadap minyak atsiri dibandingkan bakteri gram-positif karena bakteri tersebut memiliki membran luar yang mengandung rantai polisakarida hidrofilik sebagai rintangan minyak atsiri yang bersifat hidrofob sehingga aktivitas antibakteri minyak atsiri dalam melawan bakteri gram negatif menjadi lemah.

Berbeda dengan bakteri Escherichia coli dan Shigella sonnei, pada konsentrasi 8 dan 10\% minyak kemangi telah efektif menghambat bakteri Salmonella enteritidis. Hal ini disebabkan karena kemungkinan bakteri tersebut memiliki aktivitas metabolisme yang berbeda dengan bakteri Escherichia coli maupun Shigella sonnei. Bakteri Salmonella enteritidis diduga memiliki aktivitas metabolisme yang lebih rendah sehingga ribosom lambat untuk mensintesis protein. Pada bakteri gram negatif, protein porin yang terdapat pada dinding sel berfungsi sebagai perintang molekul-molekul yang mampu melewati membran luar. Apabila protein pada membram telah rusak atau terdenaturasi maka zat antibakteri dapat leluasa masuk sehingga aktivitas bakteri menjadi terhambat.

Berdasarkan hasil penelitian ini, dapat diketahui bahwa minyak kemangi (Ocimum americanum L.) hasil perkolasi dari bagian batang dan daun dapat digunakan sebagai antibakteri pada bakteri Sallmonela enteritidis, yang merupakan salah satu bakteri penyebab diare. Hal ini merupakan salah satu alternatif untuk mengurangi penggunaan antibiotik sintetis yang memiliki beberapa kelemahan karena efek samping yang ditimbulkan dari pemakaiannya yang terus-menerus.

\section{KEPUSTAKAAN}

Burt S, 2004. Essential Oils: Their Antibacterial Properties and Potential Applications in Foods: a review. Int. J. Food Microbiol. 94, 223-253.

Deresse D dan Awade M, 2009. Assessment of the Antibacterial Effect of Crude Preparation of Garlic (Allium sativa) on Diarrhea causing Bacteria, An in Vitro Study. Asian Journal of Medical Sciences. 1, 1, 12-14.

Falah R, 2007. Antibiotik Sang Penyelamat yang Bisa Jadi Musuh. Tersedia: http://www.ridhanif.multiply.com/AntibiotikSang-Penyelamat-yang-Bisa-Jadi-Musuh [23 Februari 2010]

Gill AO, Delaquis P, Russo P, dan Holley RA, 2002. Evaluation of Antilisterial Action of Cilantro Oil on Vacuum packed Ham. Int. of Food Microbiol. 73, 83-92.

Gomez KA dan Gomez AA, 1995. Prosedur Statistik Untuk Penelitian Pertanian. Edisi Kedua. Jakarta: UI Press.

Hadipoentyanti E dan Wahyuni S, 2008. Keragaman Selasih (Ocimum Spp) Berdasarkan Karakter Morfologi, Produksi dan Mutu Herba. Jurnal Litri. 14, 4, 141-148.

Holley RA dan Patel D, 2005. Improvement in Shelf-life and Safety of Perishable Food by Plant Essential Oils and Smoke Antimicrobiol. Int. of Food Microbiol. 22, 273-292.

Inoyue S, Toshio T dan Hideyo Y, 2000. Antibacterial Activity of Essential Oils and Their Major Constituents Against Respiratory Tract Pathogens by Gaseous Contact. Journal of Antimicrobial Chemotherapy. 47, 5, 565-573. 
Kardinan A, 2007. Potensi Selasih sebagai Repellent terhadap Nyamuk Aedes aegypti. Jurnal Litri. 13, 2, ISSN 08538212.

Knobloch K, et al., 1989. Antibacterial and Antifungal Properties of Essential Oil Components. J. of Essential Oils Research. 1, 119-128.

Kusnadi, 2003. Mikrobiologi Edisi Revisi. UPI Press, Bandung. Maryati FRS dan Rahayu T, 2007. Uji Aktivitas Antibakteri Minyak Atsiri Daun Kemangi (Ocimum basilicum L.) terhadap Staphylococcus aureus dan Escherichia coli. Jurnal Penelitian Sains dan Teknologi. 8, 1, 30-38.

Melendez PA dan Capriles VA, 2006. Antibacterial Properties of Tropical Plants from Puerto Rico. Phytomedicine. 13: 272-276.

Patharakon T, Teerakul A, Nuanchawee W, Amornrat P, dan Sunanta R, 2010. Antibacterial Activity and Cytotoxicity of the Leaf Essential Oil of Morus rotunbiloba Koidz. Journal of Medicinal Plants Research. 4, 9: 837-843.

Samy RP, 2005. Antimicrobial Activity of Some Medicinal Plants from India. Fitoterapia. 76: 697-699.
Sastrohamidjojo H, 2004. Kimia Minyak Atsiri. Yogyakarta: UGM Press.

Silverstein RM, 1991. Spectrometric Identification of Organic Compounds. Edisi ke-5. Singapore: Jhon Willey\&Sons.

Sirait N, 2008. Penggunaan Berbagai Jenis Tanaman Obat untuk Menanggulangi Bau Badan. Warta Penelitian dan Pengembangan Tanaman Industri. 14, 3, ISSN 08538204.

Thaweboon S dan Thaweboon B, 2009. In Vitro Antimicrobial Activity of Ocimum americanum L. Essential Oil Against Oral Microorganisms. Southeast Asian J Trop Med Public Health. 40: 5.

Wannissoma B, Jarikasemb S, Siriwangchaib T, dan Thubthimthed S, 2005. Antibacterial Properties of Essential Oils ftom Thai Medical Plants. Fitoterapia. 76: 233-236.

Yuharmen EY dan Nurbalatif, 2002. Uji Aktivitas Antimikroba Minyak Atsiri dan Ekstrak Metanol Lengkuas (Alpinia galanga). Jurnal Korespondensi Jurusan Kimia FMIPA Universitas Riau.

Reviewer: Dr. Hamidah 